\section{Studia}

\section{z Filologii Polskiej i Słowiańskiej}

DOI: $10.11649 /$ sfps.2563
Studia z Filologii Polskiej i Słowiańskiej, 56

Warszawa 2021

Article No. 2563

Citation:

Banasiak J. (2021). Habitualne czasowniki wyrażające czystą kauzację w języku bułgarskim: w ujęciu syntaktyczno-leksykograficznym. Studia z Filologii Polskiej i Słowiańskiej, 56, Article 2563. https://doi.org/10.11649/sfps.2563

\author{
Jakub Banasiak \\ (Instytut Slawistyki Polskiej Akademii Nauk, Warszawa)
}

\title{
Habitualne czasowniki wyrażające czystą kauzację w języku bułgarskim: w ujęciu syntaktyczno-leksykograficznym ${ }^{1}$
}

\section{Uwagi wstępne}

O relacji przyczynowo-skutkowej w jej warstwie pojęciowej pisano już wiele, m.in. dlatego, że stanowi ona jedno $\mathrm{z}$ ważniejszych pytań ontologii (Ajdukiewicz, 1983, s. 124) oraz metodologii ogólnej (Apanowicz, 2002, s. 24). Z językoznawczego punktu widzenia relacja ta jest relewantna ze względu na swój uniwersalny charakter (tzw. universal word w ujęciu A. Wierzbickiej) (Wierzbicka, 2004). Wydaje się jednak, że nadal warto prowadzić empiryczne badania nad wykładnikami tej kategorii w poszczególnych językach naturalnych. W niniejszym opracowaniu z rozmysłem ograniczę się do prezentacji wyrażeń predykatywnych semantycznie derywowanych od centralnych dla omawianej kategorii predykatorów oznaczających

${ }^{1}$ W pracy korzystano z infrastruktury badawczej CLARIN-PL http://clarin-pl.eu

This is an Open Access article distributed under the terms of the Creative Commons Attribution 3.0 PL License (creativecommons.org/licenses/by/3.0/pl/), which permits redistribution, commercial and non-commercial, provided that the article is properly cited. (c) The Author(s) 2021.

Publisher: Institute of Slavic Studies, Polish Academy of Sciences

[Wydawca: Instytut Slawistyki Polskiej Akademii Nauk] 
tzw. dokonaność prostą (abstrakcję od rozciągłości w czasie) w języku bułgarskim (por. niżej). Opracowanie prezentujące podstawowy (dokonany prosty) predykat przyczynowo-skutkowy w języku polskim i bułgarskim zawiera monografia Procesy nominalizacyjne $w$ zdaniach wyrażających relację przyczynowo-skutkowa (na materiale języka polskiego i bułgarskiego) (Banasiak, 2020; por. też Banasiak, 2018; Toops, 1984; Kiklewicz i in., 2019).

Zjawiska związane z rozumianym semantycznie aspektem, który stanowi składnik immanentnej struktury pojęciowej predykatów, leżą u podstaw wyróżnienia jednostek predykatywnych typu werbalnego ujętych w niniejszym opracowaniu. Aspekt modelowany jest jednak w oparciu o nowoczesny model S. Karolaka (Karolak, 2008; por. też Mazurkiewicz-Sułkowska, 2008; Korytkowska, 2013) i należy podkreślić, że podejście to różni się od tradycyjnego wyodrębniania „par aspektualnych” (bg. „видови двойки“), które sugerować by mogło, że wyrażenia predykatywne jak gdyby „odmieniają się” przez aspekt.

W swoim opracowaniu poświęconym językowi polskiemu S. Karolak określa dokonane pojęcie przyczyny, jako pojęciowy odpowiednik czasowników typu pol. spowodować, wywołać, pociagnąć za soba (Karolak, 2002, s. 24). Analogicznie w języku bułgarskim za jego standardowy wykładnik uznać można (maksymalnie neutralny) czasownik bułg. предизвика (forma pierwszej osoby stanowi jednak efekt procesów kondensacji treści i dlatego w pracy stosuję formy 3 osoby jako wyrażenia hasłowe) (por. Banasiak, 2020, s. 56). Zgodnie z semantycznym modelem aspektu tegoż autora (Karolak, 2008), pojęcie to może stanowić punkt wyjścia do tworzenia bardziej złożonych konfiguracji aspektualnych. Objęty badaniem zbiór jednostek można parafrazować przy użyciu czasownika bg. предизвиква w jego lekturze habitualnej.

Pod pojęciem werbalnych niedokonanych wykładników badanej relacji rozumiem szereg form, których cechą wspólną jest kompatybilność z gramemami czasu teraźniejszego. Należy podkreślić, że formy te przeważnie realizują inne predykaty niż podstawowy dokonany prosty predykat kauzatywny (wyjątek stanowią tu formy typu praesens historicum, w których dochodzi do neutralizacji opozycji aspektualnych). To, co moim zdaniem pozwala je uwzględnić w ramach rozważań o czystej kauzacji w szerokim sensie (a zatem nieograniczonej jedynie do dokonaności), to obecność tych samych dwóch typów pozycji predykatowo-argumentowych.

Pozycje te modeluję w oparciu o koncepcję struktury predykatowo-argumentowej M. Korytkowskiej (Korytkowska, 1992). Pewne novum stanowi jej odniesienie do predykatów otwierających dwie nieprzedmiotowe pozycje pre- 
dykatowo-argumentowe. Przyjęte założenia wypływają z analizowanej materii językowej, którą podobnie jak wypadku pozycji przedmiotowych cechuje niejednoznaczna relacja pomiędzy pozycją syntaktyczną frazy argumentowej a jej wartością semantyczną (typem pozycji predykatowo-argumentowych), por.

bg. Това произлиза от онова. vs Това довежда до онова.

Struktura semantyczna konstrukcji omawianego typu może być oddana przez następującą formułę logiczną: $\mathrm{P}_{\mathrm{HC}}\left(\mathrm{p}_{\text {Caus }} ; \mathrm{p}_{\mathrm{Eff}}\right)$, gdzie:

$\mathrm{P}_{\mathrm{HC}} \quad-$ habitualny predykat typu kauzatywnego

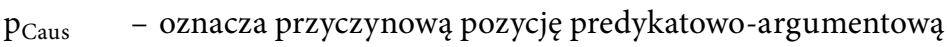

peff - oznacza skutkową pozycję predykatowo-argumentową (por. Banasiak, 2020; Kiklewicz \& Korytkowska, 2010).

Kolejność pozycji argumentowych w formule logicznej odpowiada natomiast relacji następstwa, która je wiąże.

$\mathrm{W}$ opracowaniu zrezygnowałem $\mathrm{z}$ analizy jednostek typu bg. $e$ / cmaвa причина/повод/резултат/следствие itp. Wydaje się, że zdania $\mathrm{z}$ takimi formami można by podzielić na dwie grupy:

- po pierwsze takie, w których istotnie występuje tzw. orzeczenie imienne, a forma czasownika być pełni funkcję copuli, ich znaczeniem jest zaliczenie argumentu realizowanego przez podmiot do pewnej klasy (tu klasy przyczyn lub skutków danego stanu rzeczy), por. np.

- bg. Това е причина на непрекъснато нарастване на държавните дългове.

- bg. Това е следствие на факта, че нашите страни успяха да се поучат от кризите в средата и втората част на 90-те години на миналия век.

- po drugie takie, w których w istocie wyraża się tzw. znak równości (tożsamość) dwóch argumentów (por. Koseska-Tosheva \& Gargov, 1990, ss. 140-147; Roszko, 2004, ss. 42-45), por. np.

- bg. Това е причината за инвазията на хуните.

- bg. Това е резултатьт на анализите ни, който ще представим на Комисията в Брюксел.

W obu wskazanych wypadkach odpowiednio relacja tożsamości i „bycie przyczyną” lub „bycie skutkiem” mają jednak charakter statyczny, a konstytuujące je pojęcia wyrażają aspekt ciągły i denotują permanentne stany rzeczy (por. Karolak, 2008, ss. 70-85). W przypadku orzekania tożsamości warto 
zwrócić uwagę na zespolenie nazwy jednego z terminałów relacji przyczynowo-skutkowej z formą rodzajnika.

Pod pojęciem czystej kauzacji w pracy rozumiem stosunkowo proste semantycznie predykaty oznaczające relację przyczynowo-skutkową w wersji podstawowej (dokonaność prosta) oraz derywowane od nich pojęcia o aspektach złożonych (stanowiący obiekt badania w niniejszym opracowaniu predykat habitualny). W polszczyźnie realizują je odpowiednio jednostki spowodować, powodować; w języku bułgarskim предизвика, предизвиква. Określenie „czysta” oznacza brak dodatkowych treści w semantyce omawianych jednostek.

Funkcjonowanie wyrażeń predykatywnych omawianego typu zaprezentowano na przykładzie następujących jednostek: bg. води, довежда, докарва, идва от (причината), предизвиква, причинява, произлиза, произтича. Jednostkom bułgarskim roboczo przyporządkowano w słowniczku funkcjonalne ekwiwalenty w języku polskim (który to stanowi jedynie swoiste tło $w$ artykule). Przykłady zostały zasadniczo wyekscerpowane z Internetu i korpusów (pojedyncze zdania zostały skonstruowane i sprawdzone pod względem poprawności przez rodzimego użytkownika języka bułgarskiego). Wybór powyższych czasowników motywowany był przede wszystkim ich stosunkowo ubogą semantyką (a zatem faktem, że realizują one czysty habitualny predykat przyczynowo-skutkowy) oraz wyrazistością strukturalną. Ta ostatnia skłoniła do objęcia badaniem jednostek o odwróconej strukturalizacji pozycji argumentowych (konwersywy typu: bg. произтичa, произлиза). Obok powyższej grupy sytuują się tradycyjnie wyróżnianie czasowniki kauzatywne (bg. убивам) (por. Dineva, 1985). Stanowią one przykład wpływu procesów leksykalizacyjnych na przejawianie się pozycji predykatowo-argumentowych. Są efektem procesu inkorporacji nieprzedmiotowej pozycji predykatowo-argumentowej w rdzeń czasownika wyrażającego (w skompresowanej formie) drugi $\mathrm{z}$ argumentów propozycjonalnych oraz relację typu przyczynowo-skutkowego. Formalizacje tego rodzaju stanowią przykład asymetrii między liczbą pojęć a liczbą ich dyskretnych wykładników. Zasadniczo w językoznawstwie analitycznym przyjmuje się, że bardziej rozczłonkowane wykładniki względnie prostych (-szych) pojęć stanowią przeważnie formalizacje podstawowe, natomiast skompresowane wykładniki stanowią rezultat procesów kondensacji treści. $Z$ tego powodu wydaje się, że wybrane jednostki lepiej (w bardziej rozczłonkowany sposób) oddają semantykę habitualnych zdań wyrażających relację przyczynowo-skutkową. 
Jednocześnie odrzuciłem analizę szeregu bliskoznacznych czasowników typu: bg. детерминира, обуславя. Oznaczają one pewnego rodzaju relacje między dwoma argumentami propozycjonalnymi, ale nie podlegają parafrazie przy użyciu jednostki предизвиква, por.

bg. Еволюиията детерминира живота на планетата Земя.夫 Еволюиията предизвиква живота на планетата Земя.

Osobny problem stanowi kwestia delimitacji wyrażenia predykatywnego i argumentu propozycjonalnego. W związku z uznaniem analitycznych konstrukcji werbonominalnych typu: bg. буди съмнение za jednostki języka odrzucono możliwość ich interpretacji jako dyskretnych realizacji argumentu propozycjonalnego i predykatu.

Zgodnie z przyjętymi założeniami teoretycznymi wskazane powyżej formy werbalne zostały uwzględnione jedynie w wypadku ich lektury nieaktualnej, a zatem odrzucono zdania o interpretacji telicznej, w której nadawca komunikatu wyraża „ciągły stan rzeczy (proces lub czynność), który (która) w przekonaniu mówiącego prowadzi do zaistnienia stanu rzeczy rezultatywnego" (Karolak, 2008, s. 147), por. np.

Дупката в корпуса на кораба предизвиква (сега) това, че корабът mъне. (por. też interpretacja czasownika tonąć Karolak, 2008, s. 148).

Na koincydencję formalną czasowników habitualnych (habitualno-potencjalnych, nieograniczenie iteratywnych) $\mathrm{z}$ innymi formami niedokonanymi zwraca uwagę S. Karolak (Karolak, 2008, s. 177). Warto odnotować również, że habitualno-potencjalne czasowniki omawianego typu dopuszczają lekturę ogólną nazw generalnych (ich użycie w pozycjach przy predykatach aktualnych skutkuje semantyczną niezupełnością) (por. Karolak, 2001, ss. 315-335), por. np.

bg. Пушенето води до рак.

bg. Пушенето води до смғрт.

bg. Тютюнопушенето причинява рак.

Zwraca jednak uwagę fakt, że wystąpienie nazwy generalnej w pozycji przy verbum omawianego typu nie musi wiązać się z użyciem formy rodzajnika. Co więcej badana relacja bywa w tym względzie niesymetryczna. W powyższych przykładach pozycja skutkowa nie jest użyta w odniesieniu do całej swojej ekstensji, ponieważ np. nie każda śmierć jest rezultatem palenia tytoniu. Można by je parafrazować z użyciem konstrukcji biernych typu бива причинен, por.

bg. Синузитът бива причинен от възпаление на носната лигавица. 
Denotatywnie (mimo obecności rodzajnika) opisują one ten sam typ sytuacji, a informacja o odniesieniu nie do wszystkich wystąpień „skutku danego typu” jest tym razem zakodowana $\mathrm{w}$ formie $6 u в a$. Oczywiście relacja omawianego typu może również przebiegać symetrycznie pod kątem określonościowym, por. np.

bg. Наличието на този ген причинява болестта.

W zdaniach takich orzeka się bezwyjątkowo, że skutek danego typu występuje jedynie w rezultacie danej przyczyny. Różnice te są zatem niewątpliwie relewantne komunikacyjnie.

Potencje składniowe objętych badaniem jednostek zostaną zaprezentowane poniżej $\mathrm{w}$ formie słowniczka semantyczno-syntaktycznego, gdzie poszczególnym składnikom poziomu semantycznego przyporządkowano ich korelaty formalne. Wśród ukazanych zjawisk szczególną uwagę zwrócono na procesy kondensacji treści, w efekcie których argument propozycjonalny jest realizowany przez formę rzeczownika abstrakcyjnego (nominalizacja), zaimka (prosentencjalizacja/pronominalizacja) lub rzeczownika o odniesieniu przedmiotowym (tzw. podniesienie argumentu przedmiotowego).

\section{Wykaz skrótów zastosowanych w słowniczku}

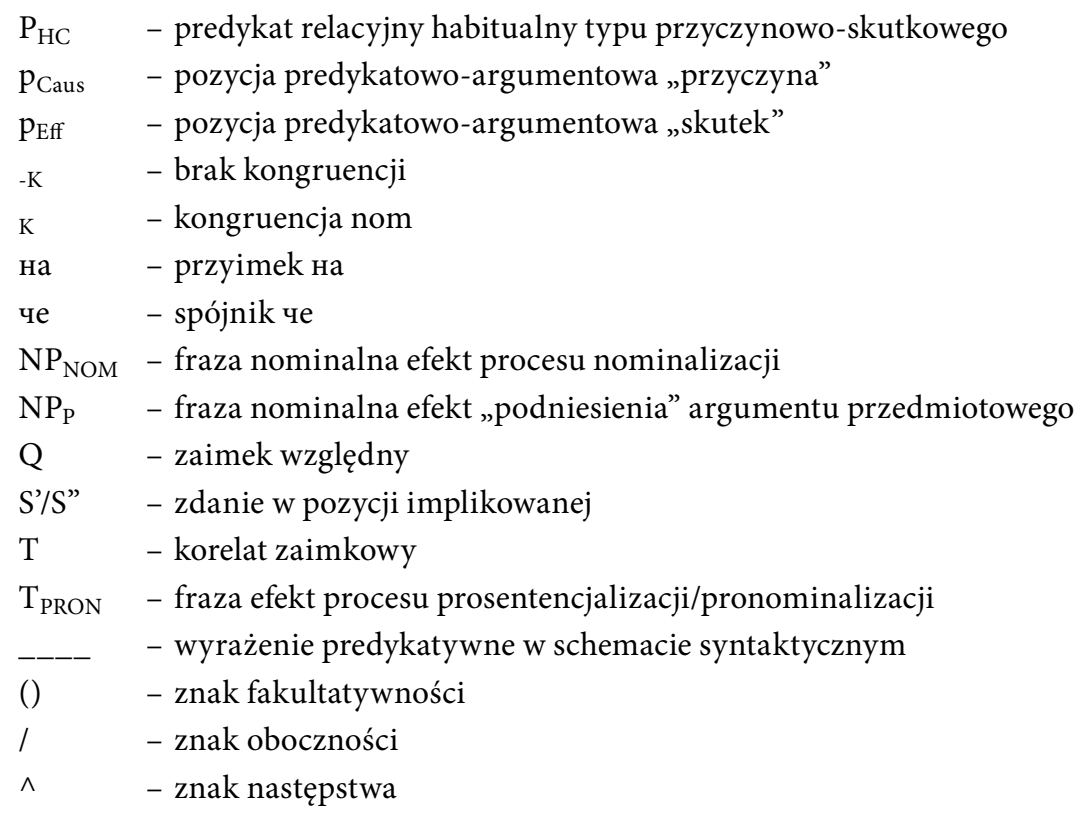




\section{Słowniczek semantyczno-syntaktyczny}

ВОДИ por. pol. PROWADZIĆ

I. wzorzec semantyczny: $\mathrm{P}_{\mathrm{HC}}\left(\mathrm{p}_{\text {Caus }}, \mathrm{p}_{\mathrm{Eff}}\right)$

II. realizacja powierzchniowa:

\begin{tabular}{|c|c|c|}
\hline \multicolumn{3}{|c|}{ Formalizacje wzorca semantycznego dla predykatora води } \\
\hline \multirow{2}{*}{ Typ realizacji argumentu } & \multicolumn{2}{|c|}{\begin{tabular}{|c|} 
Typ pozycji predykatowo-argumentowej \\
\end{tabular}} \\
\hline & $\mathrm{p}_{\text {Caus }}$ & \begin{tabular}{|c|}
$\mathrm{p}_{\mathrm{Eff}}$ \\
\end{tabular} \\
\hline A. Realizacja zdaniowa & $\mathrm{T}_{\mathrm{k}} \wedge$ че $\wedge \mathrm{S}^{\prime} / \mathrm{T}_{\mathrm{k}} \wedge \mathrm{Q}^{\wedge} \mathrm{S}^{\prime}$ & до / към^ $\mathrm{T}_{-\mathrm{k}} \wedge$ че $\wedge \mathrm{S}^{\prime \prime} / \mathrm{T}_{-\mathrm{k}} \wedge \mathrm{Q}^{\wedge} \wedge \mathrm{S}^{\prime \prime}$ \\
\hline B. Nominalizacja & $\mathrm{NP}_{\mathrm{NOM} \mathrm{k}}$ & до / към $\wedge \mathrm{NP}_{\mathrm{NOM}-\mathrm{k}}$ \\
\hline C. Pronominalizacja & $\mathrm{T}_{\mathrm{PRONk}}$ & до / към $\wedge \mathrm{T}_{\mathrm{PRON}-\mathrm{k}}$ \\
\hline D. Podniesienie argumentu & $\mathrm{NP}_{\mathrm{Pk}}$ & $\begin{array}{l}\text { ograniczone } \\
\text { до / към } \wedge \mathrm{NP}_{\mathrm{P}-\mathrm{k}}\end{array}$ \\
\hline
\end{tabular}

III. wzorzec syntaktyczny:

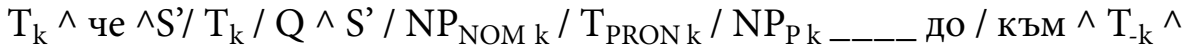
че $\wedge S^{\prime \prime} / \mathrm{T}_{-\mathrm{k}} \wedge \mathrm{Q} \wedge \mathrm{S}^{\prime \prime} / \mathrm{NP}_{\text {NOM -k }} / \mathrm{T}_{\text {PRON -k }}$

IV. typowe użycia:

Кофеингт води до физиологическа и физическа зависимост.

Подобно поведение води до това, че в някои региони много двугодишни растения се смятат за едногодишни.

Физическата зависимост води до това.

Това, как се държиш води до това, че хората не си падат по тебе.

Генетично обусловеният недостиг на този ензим води към заболяването гликогеноза тип II, засягащцо органите, депа на гликогена.

Умствената активност води към това, което наричаме мъдрост.

Тютюнопушенето също така води до рак на тарингса, устата, гърлото, бъбреиите, панкреаса и стомаха.

V. uwagi: możliwe tzw. rozszczepienie argumentu propozycjonalnego, por.: Първо, дългогодичната липса на идеологическа алтернатива на десния консенсус сред политическите партии в България води до това сред симпатизанти на основните „сбперници“в волитиката да няма различия във вижданията. 
Jakub Banasiak Habitualne czasowniki wyrażające czystą kauzację w języku bułgarskim...

\section{ДОВЕЖДА por. pol. DOPROWADZAĆ}

I. wzorzec semantyczny: $\mathrm{P}_{\mathrm{HC}}\left(\mathrm{p}_{\text {Caus }}, \mathrm{p}_{\mathrm{Eff}}\right)$

II. realizacja powierzchniowa:

\begin{tabular}{|c|c|c|}
\hline \multicolumn{3}{|c|}{ Formalizacje wzorca semantycznego dla predykatora довежда } \\
\hline \multirow{2}{*}{ Typ realizacji argumentu } & \multicolumn{2}{|c|}{ Typ pozycji predykatowo-argumentowej } \\
\hline & $\mathrm{p}_{\text {Caus }}$ & $\mathrm{p}_{\mathrm{Eff}}$ \\
\hline A. Realizacja zdaniowa & $\mathrm{T}_{\mathrm{k}} \wedge$ че $\wedge \mathrm{S}^{\prime} / \mathrm{T}_{\mathrm{k}} \wedge \mathrm{Q}^{\wedge} \mathrm{S}^{\prime}$ & до / към $\wedge \mathrm{T}_{-\mathrm{k}} \wedge$ че $\wedge \mathrm{S}^{\prime \prime} / \mathrm{T}_{-\mathrm{k}} \wedge \mathrm{Q} \wedge \mathrm{S}^{\prime \prime}$ \\
\hline B. Nominalizacja & $\mathrm{NP}_{\mathrm{NOM} \mathrm{k}}$ & до / към $\wedge$ NP $P_{\mathrm{NOM}-\mathrm{k}}$ \\
\hline C. Pronominalizacja & $\mathrm{T}_{\text {PRONk }}$ & до / към $\wedge \mathrm{T}_{\text {PRON -k }}$ \\
\hline D. Podniesienie argumentu & $\mathrm{NP}_{\mathrm{Pk}}$ & ograniczone до / към $\wedge$ $\mathrm{NP}_{\mathrm{P}-\mathrm{k}_{\mathrm{k}}}$ \\
\hline
\end{tabular}

III. wzorzec syntaktyczny:

$\mathrm{T}_{\mathrm{k}} \wedge$ че $\wedge \mathrm{S}^{\prime} / \mathrm{T}_{\mathrm{k}} \wedge \mathrm{Q}^{\wedge} \mathrm{S}^{\prime} / \mathrm{NP}_{\mathrm{NOM} \mathrm{k}} / \mathrm{T}_{\mathrm{PRON} \mathrm{k}} / \mathrm{NP}_{\mathrm{P} \mathrm{k}}$ до $\wedge \mathrm{T}_{-\mathrm{k}} \wedge$ че $\wedge \mathrm{S}^{\prime \prime} / \mathrm{T}_{-\mathrm{k}} \wedge \mathrm{Q} \wedge \mathrm{S}^{\prime \prime} / \mathrm{NP}_{\text {NOM -k }} / \mathrm{T}_{\text {PRON }-\mathrm{k}}$

IV. typowe użycia:

Поради това ерозията на нравствеността винаги в края на краищата довежда към разрушаване на законността.

Първият пролетен преглед винаги довежда до безпорядък.

Именно този процес често довенда до това, че главата на току-щзо роденото бебе прилича на леко заострен в задната си част пбпеш.

Болестта довежда до нарушения, свғрзани с крғвообращението, които могат да причинят задух, болка в областта на гърдите, замаяност, проблеми с митралната клапа и др.

Това довежда до това, че се оказва невъзможно да се оцени малката разлика в честотите и като следствие от това - съществено се намалява чувствителността на прибора.

Споровете винаги довеждат до лоши последствия.

Пушенето довежда до това.

Това често довежда до тумор.

V. uwagi: rzadko możliwe jest zastąpienie przyimka do przez przyimek $\kappa b \mathcal{M}$, które ma o wiele regularniejszy charakter dla czasownika $в o \partial u ;$ możliwe tzw. rozszczepienie argumentu propozycjonalnego, por.:

Хората с глупостта си довеждат до хиляди трагедии. 
Jakub Banasiak Habitualne czasowniki wyrażające czystą kauzację w języku bułgarskim...

\section{ДОКАРВА por. pol. DOPROWADZAĆ}

I. wzorzec semantyczny: $\mathrm{P}_{\mathrm{HC}}\left(\mathrm{p}_{\text {Caus }}, \mathrm{p}_{\mathrm{Eff}}\right)$

II. realizacja powierzchniowa:

\begin{tabular}{|c|c|c|}
\hline \multicolumn{3}{|c|}{ Formalizacje wzorca semantycznego dla predykatora докарва } \\
\hline \multirow{2}{*}{ Typ realizacji argumentu } & \multicolumn{2}{|c|}{ Typ pozycji predykatowo-argumentowej } \\
\hline & $\mathrm{p}_{\text {Caus }}$ & $\mathrm{p}_{\text {Eff }}$ \\
\hline A. Realizacja zdaniowa & $\mathrm{T}_{\mathrm{k}} \wedge$ че $^{\wedge} \mathrm{S}^{\prime} / \mathrm{T}_{\mathrm{k}} \wedge \mathrm{Q}^{\wedge} \mathrm{S}^{\prime}$ & $($ до $) \wedge \mathrm{T}_{-\mathrm{k}} \wedge$ че $\wedge \mathrm{S}^{\prime \prime} / \mathrm{T}_{-\mathrm{k}} \wedge \mathrm{Q}^{\wedge} \mathrm{S}^{\prime \prime}$ \\
\hline B. Nominalizacja & $\mathrm{NP}_{\mathrm{NOM}} \mathrm{k}$ & $($ до $) \wedge \mathrm{NP}_{\mathrm{NOM}-\mathrm{k}}$ \\
\hline C. Pronominalizacja & $\mathrm{T}_{\text {PRONk }}$ & $($ до $) \wedge \mathrm{T}_{\mathrm{PRON}-\mathrm{k}}$ \\
\hline D. Podniesienie argumentu & $\mathrm{NP}_{\mathrm{Pk}}$ & $\begin{array}{l}\text { ograniczone } \\
\text { до } \wedge N_{P_{-k}}\end{array}$ \\
\hline
\end{tabular}

III. wzorzec syntaktyczny:

$\mathrm{T}_{\mathrm{k}} \wedge$ че $\wedge \mathrm{S}^{\prime} / \mathrm{T}_{\mathrm{k}} \wedge \mathrm{Q}^{\wedge} \mathrm{S}^{\prime} / \mathrm{NP}_{\mathrm{NOM} \mathrm{k}} / \mathrm{T}_{\mathrm{PRON} \mathrm{k}} / \mathrm{NP}_{\mathrm{P} \mathrm{k}}$ (до) $\wedge \mathrm{T}_{-\mathrm{k}} \wedge$ че $\wedge \mathrm{S}^{\prime \prime} / \mathrm{T}_{-\mathrm{k}} \wedge \mathrm{Q} \wedge \mathrm{S}^{\prime \prime} / \mathrm{NP}_{\mathrm{NOM}-\mathrm{k}} / \mathrm{T}_{\mathrm{PRON}-\mathrm{k}}$

IV. typowe użycia:

Прекалено ниската предавка при спускане по хлъзгав пбт докарва до това, че двигателят не успява да навакса скоростта на автомобила. Всяко замазване на истината ни докарва до това дередже - хората да се чувстват изльгани.

Футбол е това, той винаги докарва до викове, крясъии, дивашко поведение, еубория, неконтролируемост.

Все още голяма част от мъжете не обрғщат внимание на брғсненето, използват своя си техника, която не винаги е правилна, не щади кожата и често докарва до раздразнението иे.

Това докарва до проблеми в самото устройство.

Естествено, че докарват до това.

Палмовото масло докарва тумор.

V. uwagi: możliwe tzw. rozszczepienie argumentu propozycjonalnego, por.: Жените със своята езикова компетентност докарват до по-малко недоразумения в сравнение с мъжете. 
Jakub Banasiak Habitualne czasowniki wyrażające czysta kauzację w języku bułgarskim...

ИДВА (ОТ ПРИЧИНАТА) por. pol. BRAĆ SIĘ (Z TEJ PRZYCZYNY)

I. wzorzec semantyczny: $\mathrm{P}_{\mathrm{HC}}\left(\mathrm{p}_{\text {Caus }}, \mathrm{p}_{\mathrm{Eff}}\right)$

II. realizacja powierzchniowa:

\begin{tabular}{|c|c|c|}
\hline \multicolumn{3}{|c|}{ Formalizacje wzorca semantycznego dla predykatora идва (от причината) } \\
\hline \multirow{2}{*}{ Typ realizacji argumentu } & \multicolumn{2}{|c|}{ Typ pozycji predykatowo-argumentowej } \\
\hline & $\mathrm{p}_{\text {Caus }}$ & $\mathrm{p}_{\mathrm{Eff}}$ \\
\hline A. Realizacja zdaniowa & от $\wedge \mathrm{T}_{-\mathrm{k}} \wedge$ че $\wedge \mathrm{S}^{\prime}$ & $\mathrm{T}_{\mathrm{k}} \wedge$ че $\wedge \mathrm{S}^{\prime \prime} / \mathrm{T}_{\mathrm{k}} \wedge \mathrm{Q}^{\wedge} \mathrm{S}^{\prime \prime}$ \\
\hline B. Nominalizacja & от $\wedge \mathrm{NP}_{\mathrm{NOM}-\mathrm{k}}$ & $\mathrm{NP}_{\mathrm{NOM} \mathrm{k}}$ \\
\hline C. Pronominalizacja & OT $\wedge \mathrm{T}_{\text {PRON }-\mathrm{k}}$ & $\mathrm{T}_{\text {PRONk }}$ \\
\hline D. Podniesienie argumentu & от $\wedge \mathrm{NP}_{\mathrm{P}-\mathrm{k}}$ & $\mathrm{NP}_{\mathrm{Pk}}$ \\
\hline
\end{tabular}

III. wzorzec syntaktyczny:

$\mathrm{T}_{\mathrm{k}} \wedge$ че $\wedge \mathrm{S}^{\prime \prime} / \mathrm{T}_{\mathrm{k}} \wedge \mathrm{Q} \wedge \mathrm{S}^{\prime \prime} / \mathrm{NP}_{\mathrm{NOM} \mathrm{k}} / \mathrm{T}_{\mathrm{PRON} \mathrm{k}} / \mathrm{NP}_{\mathrm{Pk} \text {-__- }}$ от $\wedge \mathrm{T}_{-\mathrm{k}} \wedge$ че $\wedge \mathrm{S}^{\prime} / \mathrm{NP}_{\mathrm{NOM}-\mathrm{k}} / \mathrm{T}_{\mathrm{PRON}-\mathrm{k}} / \mathrm{NP}_{\mathrm{P}-\mathrm{k}}$

IV. typowe użycia:

Болестта идва от бактерии, пренасяни от бълхи и пльхове.

Щастието винаги идва от благосклонността на съдбата.

Понякога тъгата идва от източник.

Скромността понякога идва от преувеличена гордост.

Законодателни проблеми винаги идват от неуредиии в нормативната уредба.

Това винаги идва от семейството.

При нас парадоксът идва от това, че във всяка една ситуаиия се изисква PCR тест, който да верифицира дали човекът е заразоносител. Според мен бебетата идват от майчината обич.

В крайна сметка ракът, едно от най-опасните заболявания, често идва от това. 
Jakub Banasiak Habitualne czasowniki wyrażające czysta kauzację w języku bułgarskim...

ПРЕДИЗВИКВА por. pol. WYWOЕYWAĆ

I. wzorzec semantyczny: $\mathrm{P}_{\mathrm{HC}}\left(\mathrm{p}_{\text {Caus }}, \mathrm{p}_{\mathrm{Eff}}\right)$

II. realizacja powierzchniowa:

\begin{tabular}{|l|l|l|}
\hline \multirow{2}{*}{ Typ realizacji argumentu } & \multicolumn{1}{|c|}{ Typ pozycji predykatowo-argumentowej } \\
\cline { 2 - 3 } & \multicolumn{1}{|c|}{$\mathrm{p}_{\text {Caus }}$} & \multicolumn{1}{c|}{$\mathrm{p}_{\mathrm{Eff}}$} \\
\hline A. Realizacja zdaniowa & $\mathrm{T}_{\mathrm{k}} \wedge$ че $\wedge \mathrm{S}^{\prime} / \mathrm{T}_{\mathrm{k}} \wedge \mathrm{Q}^{\wedge} \mathrm{S}^{\prime}$ & $\mathrm{T}_{-\mathrm{k}} \wedge$ чe $\wedge \mathrm{S}^{\prime \prime} / \mathrm{T}_{-\mathrm{k}} \wedge \mathrm{Q}^{\wedge} \mathrm{S}^{\prime \prime}$ \\
\hline B. Nominalizacja & $\mathrm{NP}_{\mathrm{NOM} \mathrm{k}}$ & $\mathrm{NP}_{\mathrm{NOM}-\mathrm{k}}$ \\
\hline C. Pronominalizacja & $\mathrm{T}_{\mathrm{PRONk}}$ & $\mathrm{T}_{\mathrm{PRON}-\mathrm{k}}$ \\
\hline D. Podniesienie argumentu & $\mathrm{NP}_{\mathrm{Pk}}$ & ograniczone $\mathrm{NP}_{\mathrm{P}-\mathrm{k}}$ \\
\hline
\end{tabular}

III. wzorzec syntaktyczny:

$\mathrm{T}_{\mathrm{k}} \wedge$ че $\wedge \mathrm{S}^{\prime} / \mathrm{T}_{\mathrm{k}} \wedge \mathrm{Q}^{\wedge} \mathrm{S}^{\prime} / \mathrm{NP}_{\mathrm{NOM} \mathrm{k}} / \mathrm{T}_{\mathrm{PRONk}} / \mathrm{NP}_{\mathrm{Pk}-\_-\mathrm{T}_{-\mathrm{k}}} \wedge$ че $\wedge \mathrm{S}^{\prime \prime} / \mathrm{T}_{-\mathrm{k}}$ $\wedge \mathrm{Q} \wedge \mathrm{S}^{\prime \prime} / \mathrm{NP}_{\mathrm{NOM}-\mathrm{k}} / \mathrm{T}_{\mathrm{PRON}-\mathrm{k}}$

IV. typowe użycia:

Играта с лихвите невинаги предизвиква това, което би следвало и пите в учебниците.

Шоколадът винаги предизвиква щастливо и блажено усещане у дамите. Глутенгт предизвиква възпаление на мозбчната тбкан.

Това често предизвиква кървене в очите, което пачиентьт вижда като нишки и петьни, появяващи се обикновено изведнбж, често през нощта. Може да се чувстваме и леко напрегнати, тьй като срещата на Луната с Уран винаги предизвиква това.

Доказано: пластмасата предизвиква тумор на черния дроб!

V. uwagi: możliwe tzw. rozszczepienie argumentu propozycjonalnego, por.: Появата на хидраденит предизвиква у мнозина ступор и неудобство. Като ияло тя е доста противоречива тичност и често предизвиква с действията си гнева на потребителите в соииалните мрежи. 
Jakub Banasiak Habitualne czasowniki wyrażające czysta kauzację w języku bułgarskim...

ПРИЧИНЯВА por. pol. POWODOWAĆ

I. wzorzec semantyczny: $\mathrm{P}_{\mathrm{HC}}\left(\mathrm{p}_{\text {Caus }}, \mathrm{p}_{\mathrm{Eff}}\right)$

II. realizacja powierzchniowa:

\begin{tabular}{|l|l|l|}
\hline \multirow{2}{*}{ Typ realizacji argumentu } & \multicolumn{1}{|c|}{ Typ pozycji predykatowo-argumentowej } \\
\cline { 2 - 3 } & \multicolumn{1}{|c|}{$\mathrm{P}_{\text {Caus }}$} & \multicolumn{1}{c|}{$\mathrm{p}_{\mathrm{Eff}}$} \\
\hline A. Realizacja zdaniowa & $\mathrm{T}_{\mathrm{k}} \wedge$ че $\wedge \mathrm{S}^{\prime} / \mathrm{T}_{\mathrm{k}} \wedge \mathrm{Q}^{\wedge} \mathrm{S}^{\prime}$ & $\mathrm{T}_{-\mathrm{k}} \wedge$ че $\wedge \mathrm{S}^{\prime \prime} / \mathrm{T}_{-\mathrm{k}} \wedge \mathrm{Q}^{\wedge} \mathrm{S}^{\prime \prime}$ \\
\hline B. Nominalizacja & $\mathrm{NP}_{\mathrm{NOM} \mathrm{k}}$ & $\mathrm{NP}_{\mathrm{NOM}-\mathrm{k}}$ \\
\hline C. Pronominalizacja & $\mathrm{T}_{\mathrm{PRONk}}$ & $\mathrm{T}_{\mathrm{PRON}-\mathrm{k}}$ \\
\hline D. Podniesienie argumentu & $\mathrm{NP}_{\mathrm{Pk}}$ & ograniczone $\mathrm{NP}_{\mathrm{P}-\mathrm{k}}$ \\
\hline
\end{tabular}

III. wzorzec syntaktyczny:

$\mathrm{T}_{\mathrm{k}} \wedge$ че $\wedge \mathrm{S}^{\prime} / \mathrm{T}_{\mathrm{k}} \wedge \mathrm{Q}^{\wedge} \mathrm{S}^{\prime} / \mathrm{NP}_{\mathrm{NOM} \mathrm{k}} / \mathrm{T}_{\mathrm{PRONk}} / \mathrm{NP}_{\mathrm{Pk}-\_-\mathrm{T}_{-\mathrm{k}}} \wedge$ че $\wedge \mathrm{S}^{\prime \prime} / \mathrm{T}_{-\mathrm{k}}$ $\wedge \mathrm{Q} \wedge \mathrm{S}^{\prime \prime} / \mathrm{NP}_{\mathrm{NOM}-\mathrm{k}} / \mathrm{T}_{\mathrm{PRON}-\mathrm{k}}$

IV. typowe użycia:

Тези стимули причиняват това, че непослушанието спрямо управляващия субект е обременено с вероятност за получаване на наказание. Магнитното поле причинява рак на млечната жлеза.

Това причинява понякога ужасни неприятности.

Това, че хората не се разбират причинява много недоразумения.

Глутенбт причинява мозбчни заболявания.

От познатите наркотици кокаинғт причинява най-силно желание за повтаряне на дозата.

Гъбична инфекиия или друго дразнене на ушите често причинява това. Мобилният телебон причинява тумор на мозъка.

V. uwagi: możliwe tzw. rozszczepienie argumentu propozycjonalnego, por.:

Тази хиперпротекиия причинява у децата, наред с други, бъдещи проблеми с фрустрация и незрялост. 
Jakub Banasiak Habitualne czasowniki wyrażające czysta kauzację w języku bułgarskim...

ПРОИЗЛИЗА por. pol. WYNIКАĆ

I. wzorzec semantyczny: $\mathrm{P}_{\mathrm{HC}}\left(\mathrm{p}_{\text {Caus }}, \mathrm{p}_{\mathrm{Eff}}\right)$

II. realizacja powierzchniowa:

\begin{tabular}{|c|c|c|}
\hline \multicolumn{3}{|c|}{ Formalizacje wzorca semantycznego dla predykatora произлиза } \\
\hline \multirow{2}{*}{ Typ realizacji argumentu } & \multicolumn{2}{|c|}{ Typ pozycji predykatowo-argumentowej } \\
\hline & $\mathrm{p}_{\text {Caus }}$ & $\mathrm{p}_{\text {Eff }}$ \\
\hline A. Realizacja zdaniowa & от $\wedge \mathrm{T}_{-\mathrm{k}} \wedge$ че $\wedge \mathrm{S}^{\prime} / \mathrm{T}_{-\mathrm{k}} \wedge \mathrm{Q}^{\wedge} \wedge \mathrm{S}^{\prime}$ & $\mathrm{T}_{\mathrm{k}} \wedge$ че $\wedge \mathrm{S}^{\prime \prime} / \mathrm{T}_{\mathrm{k}} \wedge \mathrm{Q} \wedge \mathrm{S}$ \\
\hline B. Nominalizacja & от $\wedge \mathrm{NP}_{\mathrm{NOM}-\mathrm{k}}$ & $\mathrm{NP}_{\mathrm{NOM} \mathrm{k}}$ \\
\hline C. Pronominalizacja & OT $\wedge \mathrm{T}_{\text {PRON }-\mathrm{k}}$ & $\mathrm{T}_{\text {PRONk }}$ \\
\hline D. Podniesienie argumentu & $\mathrm{oT}^{\wedge} \wedge \mathrm{NP}_{\mathrm{P}-\mathrm{k}}$ & $\mathrm{NP}_{\mathrm{Pk}}$ \\
\hline
\end{tabular}

III. wzorzec syntaktyczny:

$\mathrm{T}_{\mathrm{k}} \wedge$ че $\wedge \mathrm{S}^{\prime \prime} / \mathrm{T}_{\mathrm{k}} \wedge \mathrm{Q} \wedge \mathrm{S}^{\prime \prime} / \mathrm{NP}_{\mathrm{NOMk}} / \mathrm{T}_{\mathrm{PRON} \mathrm{k}} / \mathrm{NP}_{\mathrm{Pk}-{ }_{-}-}$от $\wedge \mathrm{T}_{-\mathrm{k}} \wedge$ че / $\mathrm{S}^{\prime} / \mathrm{T}_{-\mathrm{k}} \wedge \mathrm{Q}^{\wedge} \mathrm{S}^{\prime} / \mathrm{NP}_{\mathrm{NOM}-\mathrm{k}} / \mathrm{T}_{\mathrm{PRON}-\mathrm{k}} / \mathrm{NP}_{\mathrm{Pk}}$

IV. typowe użycia:

Обучителните проблеми на децата не винаги произлизат от липсата на мотивация или проблеми в семейството.

Някои от проблемите със зъбите и венците понякога произлизат от неправилно спазване на оралната хигиена.

Вместо от деспотичните владетели, това често произлиза от т. нар. анонимни бюрокрачии.

Ти искаш да направиш нещо и ияла нощ, се бориш, ти се намираш в борба, тази борба произлиза от тебе.

Децата произлизат от любовта.

Даже и познатият влажен мирис на земята произлиза от бактериите, които живеят в нея.

Историята винаги произлиза от това.

Това най-често произлиза от слаба връзка със сателитите. 
Jakub Banasiak Habitualne czasowniki wyrażające czystą kauzację w języku bułgarskim...

ПРОИЗТИЧА por. pol. WYNIKAĆ

I. wzorzec semantyczny: $\mathrm{P}_{\mathrm{HC}}$ ( $\left.\mathrm{p}_{\text {Caus }}, \mathrm{p}_{\mathrm{Eff}}\right)$

II. realizacja powierzchniowa:

\begin{tabular}{|l|l|l|}
\hline \multirow{2}{*}{ Typ realizacji argumentu } & \multicolumn{2}{|c|}{ Typ pozycji predykatowo-argumentowej } \\
\cline { 2 - 3 } & \multicolumn{1}{|c|}{$\mathrm{p}_{\text {Caus }}$} & \multicolumn{1}{c|}{$\mathrm{p}_{\mathrm{Eff}}$} \\
\hline A. Realizacja zdaniowa & от $\wedge \mathrm{T}_{-\mathrm{k}} \wedge$ че $\wedge \mathrm{S}^{\wedge} / \mathrm{T}_{-\mathrm{k}} \wedge \mathrm{Q}^{\wedge} \mathrm{S}^{\prime}$ & $\mathrm{T}_{\mathrm{k}} \wedge \mathrm{чe}^{\wedge} \mathrm{S}^{\prime} / \mathrm{T}_{\mathrm{k}} \wedge \mathrm{Q}^{\wedge} \mathrm{S}$ \\
\hline B. Nominalizacja & от $\wedge \mathrm{NP}_{\mathrm{NOM}-\mathrm{k}}$ & $\mathrm{NP}_{\mathrm{NOM} \mathrm{k}}$ \\
\hline C. Pronominalizacja & $\mathrm{oT}^{\wedge} \mathrm{T}_{\mathrm{PRON}-\mathrm{k}}$ & $\mathrm{T}_{\mathrm{PRON}}$ \\
\hline D. Podniesienie argumentu & от $^{\wedge} \mathrm{NP}_{\mathrm{P}-\mathrm{k}}$ & $\mathrm{NP}_{\mathrm{Pk}}$ \\
\hline
\end{tabular}

III. wzorzec syntaktyczny:

$\mathrm{T}_{\mathrm{k}} \wedge$ че $\wedge \mathrm{S}^{\prime \prime} / \mathrm{T}_{\mathrm{k}} \wedge \mathrm{Q} \wedge \mathrm{S}^{\prime \prime} / \mathrm{NP}_{\mathrm{NOMk}} / \mathrm{T}_{\mathrm{PRONk}} / \mathrm{NP}_{\mathrm{Pk}-\mathrm{C}_{-}}$от $\wedge \mathrm{T}_{-\mathrm{k}} \wedge$ че / $\mathrm{S}^{\prime} / \mathrm{T}_{-\mathrm{k}} \wedge \mathrm{Q}^{\wedge} \mathrm{S}^{\prime} / \mathrm{NP}_{\mathrm{NOM}-\mathrm{k}} / \mathrm{T}_{\mathrm{PRON}-\mathrm{k}} / \mathrm{NP}_{\mathrm{P}-\mathrm{k}}$

IV. typowe użycia:

Яснотата в светоглед произтича от бедността на неговата натура. Това произтича от липсата на достатьчно знание за работите.

Обаче проблемғт със създаването на истински ефективна ваксина произтича от това, че тя може да се създаде едва когато се идентифицира вирусният щзам, заплашващ, с пандемия.

Правоустановяващото действие произтича от това, че страните взаимно се задтлжават да считат, че правното положение е такова, каквото е закрепено в спогодбата, като няма да го оспорват занапред. Цялата власт произтича от хората.

Децата произтичат от практики, които трудно се изразяват с думи. Несигурността по отношение на третирането на IТС произтича от това, че директивата препраща към националното право.

Единият партньор е автотрофен (Автотрофни организми), а другият хетеротрофен (Хетеротрофни организми), и взаимната изгода при тях произтича именно от това. 


\section{Podsumowanie}

Objęte badaniem jednostki typu werbalnego służą do wyrażania relacji typu przyczynowo-skutkowego w kontekstach nieaktualnych. Wśród ogółu zjawisk z zakresu procesów kondensacyjnych zwraca uwagę regularna dopuszczalność podniesienia argumentu przedmiotowego w pozycji przyczynowej. Analogiczne zjawisko ma w pozycji skutkowej bardzo ograniczony charakter i wymaga uwzględnienia również wartości leksykalnej danego argumentu. Przede wszystkim stosunkowo proste propozycje o sensie egzystencjalnym dopuszczają realizację w postaci „podniesienia” argumentu przedmiotowego, por.

bg. Доказано: пластмасата предизвиква тумор на черния дроб!

Мобилният телебон причинява тумор на мозъка.

Konstrukcje takie należałoby również raczej odróżniać od stałych połączeń typu:

bg. Духовната стълба води към небето.

Omawiane w artykule czasowniki regularnie wiążą się z przysłówkowymi wykładnikami częstotliwości, które ujednoznaczniają nieaktualny (habitualno-potencjalny) charakter zdania. W wypadku niektórych jednostek zaobserwowano również tzw. rozszczepienie argumentu propozycjonalnego (por. Kiklewicz \& Korytkowska, 2010, s. 369), tj. taką formalizację, w której argument propozycjonalny jest realizowany przez wypełnienie dwóch odrębnych pozycji składniowych. Wydaje się, że w związku z częstym użyciem nieaktualnym jednostek werbalnych należałoby uwzględnić taką lekturę również w odniesieniu do wykładników innego typu (np. przyimków). Przy ich interpretacji konieczne byłoby rekonstruowanie znaczenia aspektualnego predykatu w oparciu o wartości argumentów propozycjonalnych (zwłaszcza w pozycji skutkowej, która w zdaniach fundowanych na przyimkach obligatoryjnie realizuje się zdaniowo).

\section{Bibliografia}

Ajdukiewicz, K. (1983). Zagadnienia i kierunki filozofii: Teoria poznania, metafizyka (2. wyd.). Czytelnik.

Apanowicz, J. (2002). Metodologia ogólna. Wyższa Szkoła Administracji i Biznesu.

Banasiak, J. (2018). Kilka uwag o formalizacji argumentu propozycjonalnego pCaus w zdaniach z przyimkowymi kauzatywnymi wyrażeniami predykatywnymi w języku bułgarskim. Slavia Meridionalis, 18, Article 1699. https://doi.org/10.11649/sm.1699 
Jakub Banasiak Habitualne czasowniki wyrażające czystą kauzację w języku bułgarskim...

Banasiak, J. L. (2020). Procesy nominalizacyjne $w$ zdaniach wyrażających relację przyczynowo-skutkowa (na materiale języka polskiego i bułgarskiego). Instytut Slawistyki Polskiej Akademii Nauk. https://ispan.waw.pl/ireteslaw/handle/20.500.12528/1524

Dineva, A. (1985). Semantika na kauzativnite glagoli v bŭlgarski. Bŭlgarski ezik, 1985(2), 140-148.

Karolak, S. (2001). Od semantyki do gramatyki: Wybór rozpraw. Instytut Slawistyki Polskiej Akademii Nauk (Slawistyczny Ośrodek Wydawniczy).

Karolak, S. (2002). Podstawowe struktury składniowe języka polskiego. Instytut Slawistyki Polskiej Akademii Nauk (Slawistyczny Ośrodek Wydawniczy).

Karolak, S. (2008). Semantyczna kategoria aspektu. Instytut Slawistyki Polskiej Akademii Nauk (Slawistyczny Ośrodek Wydawniczy).

Kiklewicz, A., \& Korytkowska, M. (Red.). (2010). Podstawowe struktury zdaniowe współczesnych języków słowiańskich: Białoruski, bułgarski, polski. Centrum Badań Europy Wschodniej Uniwersytetu Warmińsko-Mazurskiego.

Kiklewicz, A., Korytkowska, M., Mazurkiewicz-Sułkowska, J., \& Zatorska, A. (2019). Zintegrowany opis semantyczno-syntaktyczny czasowników bułgarskich, polskich i rosyjskich (verba cogitandi i verba sentiendi). Instytut Slawistyki Polskiej Akademii Nauk. https:// ispan.waw.pl/ireteslaw/handle/20.500.12528/1087

Korytkowska, M. (1992). Typy pozycji predykatowo-argumentowych. Instytut Slawistyki Polskiej Akademii Nauk (Slawistyczny Ośrodek Wydawniczy).

Korytkowska, M. (2013). Slawistyka polska w minionym sześćdziesięcioleciu: Synchroniczne prace językoznawcze z zakresu morfologii i składni. Rocznik Slawistyczny, 62, 39-54.

Koseska-Tosheva, V., \& Gargov, G. (1990). Bŭlgarsko-polska sŭpostavitelna gramatika: T. 2. Semantichnata kategoriia opredelenost/neopredelenost. Izdatelstvo na BAN.

Mazurkiewicz-Sułkowska, J. (2008). Wyrażanie kategorii inchoatywności w językach polskim, bułgarskim i białoruskim. Drukarnia Cyfrowa i Wydawnictwo „Piktor”.

Roszko, R. (2004). Semantyczna kategoria określoności/nieokreśloności w języku litewskim: W zestawieniu z jezzkiem polskim. Instytut Slawistyki Polskiej Akademii Nauk (Slawistyczny Ośrodek Wydawniczy).

Toops, G. H. (1984). Causativity in Bulgarian. Die Welt der Slaven: Halbjahresschrift für Slavistik, 29/8(2), 236-244.

Wierzbicka, A. (2004). Polish and universal grammar. Studies in Polish Linguistics, 1, 9-28. 


\title{
Habitual Verbs Expressing Pure Causativity in the Bulgarian Language: A Syntactic-Lexicographic Approach
}

\author{
Summary
}

This article presents the semantics and syntax of habitual verbs expressing pure causativity in Bulgarian. The linguistic data is modelled according to the predicate-argument theory with a particular focus on syntactic condensation processes. The lexical units under investigation are presented in the form of a semantic-syntactic dictionary with examples of different types of formalisations of the two opened argument positions ("cause" and "effect"). The latter of the two positions is less compatible with non-abstract nouns as the only formal exponent of the proposition. The following units were selected for the study: Bul. води, довежда, докарва, идва от (причината), предизвиква, причинява, прочзлиза, прочзтича.

\section{Habitualne czasowniki wyrażające czystą kauzację w języku bułgarskim: w ujęciu syntaktyczno-leksykograficznym}

\author{
Streszczenie
}

W artykule omówiono semantykę i składnię habitualnych czasowników wyrażających czystą kauzację w języku bułgarskim. Dane językowe zostały wymodelowane w oparciu o teorię predykatowo-argumentową ze szczególnym naciskiem położonym na procesy kondensacji syntaktycznej. Zbadane jednostki zostały zaprezentowane w formie semantyczno-syntaktycznego słownika z przykładami różnych typów formalizacji obu otwartych pozycji argumentowych („przyczyny” i „skutku”). Druga z omawianych pozycji jest 
Jakub Banasiak Habitualne czasowniki wyrażające czysta kauzację w języku bułgarskim...

mniej kompatybilna z rzeczownikami nieabstrakcyjnymi w funkcji jedynego wykładnika propozycji. Do badania wybrano następujące jednostki: bg. водu, довежда, докарва, идва от (причината), предизвиква, причинява, произтиза, произтича.

Keywords: Bulgarian language; habituality; verb; predicate-argument theory; causal relation; syntactic condensation

Słowa kluczowe: język bułgarski; habitualnosć; czasownik; teoria predykatowo-argumentowa; relacja przyczynowo-skutkowa; kondensacja syntaktyczna

Jakub Banasiak, Institute of Slavic Studies, Polish Academy of Sciences, Warsaw, Poland ORCID: https://orcid.org/0000-0002-7319-0736

Correspondence: jakub.banasiak@ispan.waw.pl

The preparation of this article was self-financed by the author.

Competing interests: The author has declared that he has no competing interests.

Publication history: Received: 2021-04-23; Accepted: 2021-09-08; Published: 2021-12-20 